LIBRES: Library and Information Science Research

Electronic Journal ISSN 1058-6768

2000 Volume 10 Issue 2; September 30

Bi-annual LIBRES 10N2

\title{
The Australian Book Auction Records
}

\section{Fiona Kells}

School of Fine Arts, Classical Studies and Archaeology

University of Melbourne

and

Stuart Kells

Department of Economics

University of Melbourne

quarle@,ozemail.com.au 


\begin{abstract}
This paper describes the Australian Book Auction Records (ABAR), a resource of information collected from auctions of old, fine and rare books. All the books in the records are connected in some way with Australasia. The authors outline the history of $A B A R$, consider the usefulness of the resource for librarians and other potential users of the data, explain the inclusion criteria of the records, and present a statistical profile of the data. The authors discuss their recommendations for supplementing the records, focusing on their contention that the results of on-line book sales should be included in future if the resource is to remain relevant for users.
\end{abstract}

\title{
Acknowledgments
}

The authors are grateful to Mrs Jill Burdon for her advice about interpreting the book auction records. 


\section{Introduction}

Sale by auction has for centuries been a favoured way of disposing of valuable books. As early as the seventeenth century there were auctioneers in England who dealt exclusively in books and paintings (Learmount, 1985). Today, there are vibrant book auction markets in Australia, Britain, the United States and many other countries.

The results of antiquarian book auctions can be valuable information for librarians, as well as for practitioners in related fields. For the buyer of old and rare books, historical market values show (though sometimes inexactly) how much is too much, and how much is a fair price. Price information is also useful for valuing collections and for prioritising acquisitions.

The scarcity of particular titles can be inferred from how often they come up for sale. The frequency with which books are offered and the prices they realise also give insight into contemporary tastes and are an indicator of developing or shifting cultural interests. In Australia, examples of recent trends in buying include the passion for books about Antarctica, and the oscillating fortunes of books connected with the Lindsay family. As well as revealing fashions, auction results can be used to identify those books that are perennially valued.

Auction records that present information about books' condition can be used to develop a picture of the typical state of copies in circulation. This information can guide decisions about whether or not to acquire imperfect copies as they come up for sale from time to time. It is useful to know that all copies of a title share the same fault (for example, browning of the leaves), or that a copy offered for sale is inferior to most other copies that appeared on the market over a given time period.

This paper documents an information resource that contains the results of a large number of book auctions. The resource is called Australian Book Auction Records (ABAR). For many years, $A B A R$ has admirably fulfilled its information role by collecting data exclusively from traditional, non-Web-based auctions. In recent years, however, developments in Web-based auctions have precipitated rapid global change in the book auction business, posing a challenge for the publishers of $A B A R$.

\section{Australian Book Auction Records}

$A B A R$ is a (usually) biennial publication which documents the results of auctions, mostly in Australia, of old, fine and rare books 'of Australasian interest.' For the purposes of $A B A R$, 'of Australasian interest' is defined as books and periodicals written by Australians, or published in Australia, or written about Australia or Australians, or about Antarctica, New Zealand or the South Pacific. More than 40,000 individual transactions have been recorded in the series since it was first published in 1969.

The early issues of $A B A R$, covering the period 1969 to 1978, were compiled by the late Mrs Margaret Woodhouse. Other commitments forced Mrs Woodhouse to stop compiling the 
series in 1979, and there was a break in the series. In 1985 Mrs Jill Burdon stepped into the breach, and she has published the series ever since. Mrs Burdon's first volume of $A B A R$ covered the years 1983 to 1985 . The entries for the first years of this volume (1983 and 1984) were prepared retrospectively from catalogues that Mrs Burdon obtained from auctioneers. Time and data constraints prevented Mrs Burdon from filling the whole gap in the series, and so there are presently no $A B A R$ entires for the years 1979 to 1982. (It would be possible to prepare a limited set of entries for these missing years, but to date no-one has taken up this task.) The latest $A B A R$ volume covered 1998 and 1999 and was published in May 2000. The next volume is due for release in early 2002.

The $A B A R$ volumes are offered for sale by the publishers (Australian Book Auction Records) and copies are kept in the National and State libraries in Australia, the University of Melbourne library and other major Australian reference collections.

The main Australian auction houses that deal in books contribute data to ABAR. Christie's, Sotheby's, Leonard Joel, Lawsons and Pioneer Books are among the firms that have contributed for many years. Since 1986, $A B A R$ has also included information from selected sales in London. The resource does not document sales in countries other than Australia and Britain. $A B A R$ documents some sales in which books were offered along with other items, as well as sales entirely of books.

All the books listed in the series were sold at rising-price, 'English' auctions. Most auctions in $A B A R$ were held by commercial auctioneers or booksellers and closely resembled the typical fine art auction in the way they were publicised and organised. The notable exceptions are the 'slow auctions' held every two years at the University of New South Wales book fair. At these events, bids are posted on a board, and bidding extends over several days. To date, twelve of these events have been recorded in $A B A R$, and together they account for 716 transactions or 1.68 per cent of the total. $A B A R$ also documents a series of twelve charity auctions (Canberra Life-line, 1975-77, 1983-91), which account for 176 transactions ( 0.4 per cent). ${ }^{[1]} A B A R$ does not presently include results from on-line book auctions.

In addition to the requirement that books must be 'of Australasian interest', the compilers of $A B A R$ have applied a minimum price cut-off. The minimum price (in nominal terms) has risen over the life of the series. Currently, books must have realised at least $\$ 45$ in the two years covered by the particular volume to be eligible for inclusion. In the first year of $A B A R$ (1969), the cut-off was five dollars. The cut-off is not applied religiously: for example, if two different copies of a book are sold in a given year and only one satisfies the price cut-off, the other will still be included.

The compilers have aimed to make the series comprehensive of sales that fall within the bounds described above. In each volume the records are organised alphabetically, principally by author's surname. Periodicals and anonymous works are referenced by title. Some books are entered more than once - for example, under the author's name and under the publisher's name. To derive the summary statistics that follow, repeat entries were removed. 
For each book listed, the following information is provided:

Price details:

- Price realised in Australian dollars. For London sales the price in British pounds is given, along with an Australian dollar equivalent, calculated using the Australian dollarBritish pound exchange rate applying at the sale. Prices are inclusive of buyer's premium.

Book details:

- Author or authors

- Title

- Date of publication

- Place of publication

- Edition (for example, 'second revised and enlarged edition')

- Number of copies or sets (for small limited editions)

- Number of volumes (if applicable)

- Condition. Any defects or faults are recorded. This information is based on the description of the book in the auctioneer's catalogue.

- Other salient details of the book-for example, whether the specific copy has a special association with the author.

- Bibliographical reference number (if the book is listed in one of the principal bibliographies of Australiana, eg. Ferguson, Beddie).

Auction details:

- Date of sale

- Auctioneer

- Whether a buyer's premium was applicable, and the level of the premium applying for the particular sale.

- Place of sale

\section{Coding the data}

$A B A R$ is not presently published in an electronic form. In order to analyse the price data, the authors coded all the records and combined them in a database. Every title in every 
volume was assigned a unique number. For example, record number 772901 - the $2901 \mathrm{st}$ title in the 1977-78 volume of $A B A R$-refers to the book A Month in the Bush of Australia by T. Walker, 1838, which was sold for $\$ 1100$ on 22 March 1978 by Christie's at the Age Gallery, Melbourne. Every sale event was also given a numeric identifier. (The $22 \mathrm{March}$ 1978 Christie's sale is number 7804 as it is the fourth sale in 1978).

\section{Profile of the data}

The following table (Table 1) shows the number of auction events covered by $A B A R$ in every year of its existence. The average annual number of sales documented in $A B A R$ is fifteen sales. The lowest coverage was achieved in each of the inception years of the two $A B A R$ series: 1969 and 1983. The total number of auction events represented in $A B A R$ is 413 sales. While the data-set records the results of auctions throughout Australia (and in London), the great majority of sales in the series were held in either Sydney or Melbourne.

On average, an auction event in $A B A R$ will account for just over 100 transactions. The largest auction documented in $A B A R$ is the 1969 sale by Theodore Bruce \& Co. of the Charles Glover Library. This sale at the Melbourne showgrounds saw 1,856 items 'of Australasian interest' sold. (We discuss below how $A B A R$ can understate the total number of books sold at an auction event.)

Table 1 also shows the number of transactions recorded in each year of $A B A R$. The number of sales events and the number of transactions have fluctuated considerably from year to year. The total number of items included to date is 42,511 items. In terms of the number of books sold, the boom years for Australiana at auction were 1970 and 1994.

In 1994, the auction firm Leonard Joel auctioned a large collection of Australiana that included many exceptionally rare books about Antarctica and the exploration of Australia. The sale catalogues, prepared by Julien Renard, filled three large volumes (and are now highly collectable in their own right). This massive sale, held from November 15 to 17, accounted for 1,621 individual items, or more than half the 1994 transactions in $A B A R$.

The table shows the value of each year's sales in 1999 dollars. ${ }^{[2]}$ The gross value of the transactions recorded in $A B A R$ is $\$ 37.2$ million. The table contains a hint that the $1980 \mathrm{~s}$ asset price boom affected the book market. The value of 1988 transactions was more than twice the value in any other year, indicating not only that the boom arrived, but that it arrived late. $\underline{[3]}$

Table 1: Number of sales, number of books, value of sales and average price for each year of $A B A R$

\begin{tabular}{|c|c|c|c|c|}
\hline Year & $\begin{array}{c}\text { Number of sales } \\
\text { covered }\end{array}$ & $\begin{array}{c}\text { Number of books } \\
\text { sold }\end{array}$ & $\begin{array}{c}\text { Total value } \\
\text { (1999 dollars) }\end{array}$ & $\begin{array}{c}\text { Average price } \\
\text { (1999 dollars) }\end{array}$ \\
\hline 1969 & 5 & 839 & 225,562 & 268.85 \\
1970 & 12 & 2,939 & $1,359,854$ & 462.69 \\
1971 & 11 & 1,729 & 627,708 & 363.05 \\
1972 & 14 & 593 & 564,042 & 951.17 \\
1973 & 18 & 1,131 & 678,737 & 600.12 \\
1974 & 12 & 1,783 & 600,157 & 336.60
\end{tabular}




\begin{tabular}{|c|c|c|c|c|}
1975 & 12 & 1,639 & 970,441 & 592.09 \\
1976 & 20 & 1,446 & 465,066 & 321.62 \\
1977 & 15 & 2,207 & 771,748 & 349.68 \\
1978 & 17 & 2,075 & 845,471 & 407.46 \\
1983 & 7 & 974 & 354,583 & 364.05 \\
1984 & 12 & 1,564 & $1,159,049$ & 741.08 \\
1985 & 10 & 1,538 & $1,510,659$ & 982.22 \\
1986 & 18 & 2,387 & $2,389,536$ & 1001.06 \\
1987 & 16 & 1,324 & 984,583 & 743.64 \\
1988 & 20 & 2,245 & $6,694,749$ & 1306.77 \\
1989 & 19 & 2,079 & $2,716,782$ & 724.50 \\
1990 & 18 & 1,376 & 996,912 & 994.73 \\
1991 & 20 & 1,725 & $1,715,907$ & 1980.65 \\
1992 & 17 & 1,404 & $2,780,834$ & 685.32 \\
1993 & 13 & 1,152 & 789,484 & 776.18 \\
1994 & 18 & 2,785 & $2,161,648$ & 714.39 \\
1995 & 15 & 941 & 672,240 & 1633.19 \\
1996 & 20 & 1,127 & $1,840,601$ & 1591.22 \\
1997 & 16 & 1,165 & $1,853,773$ & 504.38 \\
1998 & 19 & 1,265 & 638,035 & 778.03 \\
\hline 1999 & 19 & 1,079 & 839,490 & 875.25 \\
\hline $1969-99$ & 413 & 42,511 & $37,207,651$ & \\
\hline
\end{tabular}

\section{Highest prices realised}

Table 1 shows the average prices realised over the life of $A B A R$, and how they have fluctuated under the influence of occasional sales at very high prices. The following table (Table 2) shows the highest prices recorded in each year of the series. Books sold in London figure heavily in the list of highest prices, as do natural history books. In 19 of the 27 years recorded, the top prices were achieved by books about birds.

Table 2: Highest prices realised (nominal) in each year of the series

\begin{tabular}{|c|c|c|c|}
\hline Year & $\begin{array}{c}\text { Sale price \$ } \\
\text { (nominal) }\end{array}$ & Description & Auctioneer \\
\hline 1969 & 2,000 & Lycett, Views in Australia & Geoff K. Gray, Sydney \\
\hline 1970 & 16,500 & Gould, Birds of Australia & Christie's, Melbourne \\
\hline 1971 & 2,300 & $\begin{array}{c}\text { Gould, Mammals of Australia } \\
\text { Martens, Sketches in Environs of Sydney }\end{array}$ & $\begin{array}{c}\text { Christie's, Sydney } \\
\text { Leonard Joel, Melbourne }\end{array}$ \\
\hline 1972 & 2,300 & Gould \& Sharpe, Birds of New Guinea & Christie's, Sydney \\
\hline 1973 & 13,000 & Gould, Birds of Australia & Christie's, Sydney \\
\hline 1974 & 25,000 & Gould, Birds of Australia & Christie's, Melbourne \\
\hline 1975 & 7,500 & Flinders, Coasts of Van Diemen's Land & Christie's, Launceston \\
\hline 1976 & 5,500 & Gould, Birds of Australia & Christie's, Sydney \\
\hline 1977 & 6,200 & Mathews, Birds of Australia & Christie's, Melbourne \\
\hline 1978 & 30,000 & Gould, Birds of Australia & Christie's, Melbourne \\
\hline 1983 & 9,000 & Art in Australia (1916-42) & William Ellenden, Sydney \\
\hline 1984 & 15,000 & Lycett, Views in Australia & Christie's, Sydney \\
& 15,000 & Lycett, Views in Australia & Sotheby's, Sydney \\
\hline 1985 & 215,000 & Gould, Birds of Australia & Kenneth Hince, Melbourne \\
\hline 1986 & $282,871^{*}$ & Gould, Birds of Australia & Christie's, London \\
& $\left(£ 126,500^{*}\right)$ & & Christie's, London \\
\hline 1987 & $80,069^{*}$ & Gould, Birds of Australia & Leonard Joel, Melbourne \\
\hline 1988 & 280,000 & Banks, Florilegium & \multicolumn{2}{|c|}{} \\
\hline
\end{tabular}




\begin{tabular}{|c|c|c|c|}
\hline 1989 & $495,000 *$ & Gould, Birds of Australia & Sotheby's, Melbourne \\
\hline 1990 & $110,000^{*}$ & $\begin{array}{c}\text { Pelsaert, Ongeluckige voyagie van't schip } \\
\text { Batavia }\end{array}$ & Sotheby's, Melbourne \\
\hline 1991 & $\begin{array}{c}419,189^{*} \\
\left(£ 187,000^{*}\right)\end{array}$ & Gould, Birds of Australia & Christie's, London \\
\hline 1992 & $\begin{array}{c}416,772 * \\
(£ 165,000 *)\end{array}$ & Lewin, Birds of New South Wales & Sotheby's, London \\
\hline 1993 & $\begin{array}{r}125,249^{*} \\
\left(£ 56,500^{*}\right)\end{array}$ & $\begin{array}{c}\text { Lear, Illustrations of the Family of Psittacidae, } \\
\text { or Parrots }\end{array}$ & Christie's, London \\
\hline 1994 & $\begin{array}{l}163,945^{*} \\
(£ 76,300) \\
\end{array}$ & Levaillant, Histoire naturelle des perroquets & Christie's, London \\
\hline 1995 & $\begin{array}{l}149,138^{*} \\
(£ 67,500)\end{array}$ & Levaillant, Histoire naturelle des perroquets & Christie's, London \\
\hline 1996 & $354,500^{*}$ & Gould, Birds of Australia & Christie's, Melbourne \\
\hline 1997 & $\begin{array}{r}957,535^{*} \\
(£ 460,000)\end{array}$ & $\begin{array}{c}\text { Gould, Complete works (43 volumes, bound } \\
\text { by Zaehnsdorf) }\end{array}$ & Christie's, London \\
\hline 1998 & $43,700^{*}$ & $\begin{array}{l}\text { Sharpe, Monograph of the Paradiseidae, or } \\
\text { birds of paradise (bound by Zaehnsdorf) }\end{array}$ & Christie's, Sydney \\
\hline 1999 & $211,500^{*}$ & Gould, Birds of Australia & Christie's, Melbourne \\
\hline
\end{tabular}

* includes buyer's premium.

\section{Repeat sales}

Table 2 shows that some titles appear more than once in the data-set. Lycett's Views brought the top price in two years, while Gould's Birds of Australia was the most valuable title twelve times. (Birds of Australia also figured in the record-breaking sale of Gould's complete works in 1997, which — with buyer's premium - realised nearly one million Australian dollars.) The great majority of titles referenced in any one volume of $A B A R$ appear in at least one other volume of the series. One of the most frequently seen titles is Andrew Garran's Picturesque Atlas of Australasia (1886), which appears 237 times. The Magic Pudding (1918) by Norman Lindsay is another well-represented title.

Titles in the 1969-70 volume appear in that volume on average 1.38 times. Titles in the 1998-99 volume appear in that volume on average 1.36 times.

The recurrence of titles means the creation of a time series (or 'panel') of book prices is possible. However large variations in condition across different copies mean that users must be careful that they are comparing like with like. For example, the Picturesque Atlas copies range from very good to very poor condition, and appear in a variety of bindings and formats, with and without the required maps. Differences of this kind will of course significantly influence buyers' valuations.

\section{Distribution of prices}

The distribution of prices realised at the book auctions in $A B A R$ is highly skewed. There are a large number of prices at or near the minimum cut-off, and a small number of high-value sales which account for a large share of the aggregate sale value in each year. An example of these high-value sales is the sale of Gould's complete works in 1997; this single lot accounted for 53 per cent of the value of 1997 sales in the database. [4] 
The top decile of prices (top 10 per cent; 4251 books) accounts for 78 per cent of the total real value of sales. The top percentile (top 1 per cent; 425 books) accounts for 49 per cent of the total real value. Thirty-four items realised more than $\$ 100,000$ (1999 prices); 475 items realised more than $\$ 10,000$ (1999 prices).

Books sold in London account for 0.9 per cent of the number of transactions (399 items), but 20.9 per cent of the real value of transactions. The average price realised by items sold in London was $\$ 19,484$ (1999 prices) compared with an average price overall of $\$ 875$ (1999 prices).

\section{Buyers'premia}

It is typical for auctioneers to charge sellers a fee related to the sale price that is realised. This fee covers the cost of publicising and staging the auction, and is how most auctioneers turn a profit. A relatively recent feature of Australian book auctions is an additional fee levied on the buyer and calculated as a percentage of the gavel price. Such buyers' premia first appeared in $A B A R$ in 1985, at the Sotheby's sale of 16 April in Melbourne. (The Christie's sale of 14 April 1986 was the next sale in $A B A R$ to feature a buyer's premium; both sales had premia of ten per cent.) These fees had gained a foothold in European and American book auctions some years before this, and according to Learmount (1985) they featured in auctions in ancient times. All the London sales in $A B A R$ had buyers' premia.

From 1985 to 1992 all the sales in $A B A R$ with buyers' premia took place either in Melbourne or London; buyer's premia were prohibited in New South Wales until 1993. Within a decade of their first appearance in Australia, buyers' premia had become commonplace in Sydney and in Melbourne, and had spread to Hobart and elsewhere. In the latest edition of $A B A R$ (1998-99), half the auctions and 84 per cent of transactions involved buyers' premia. A usual premium rate at the auctions in $A B A R$ is ten per cent, though premia of fifteen per cent and higher are sometimes seen, and stepped premia (eg. fifteen per cent up to $£ 30,000$; ten per cent thereafter) have been applied in Australia and in Britain. The total value of buyers' premia applied in the 1998-99 sales was approximately $\$ 164,000$ or 11.1 per cent of the total real value (\$1.48 million).

Books sold at Australian auctions after 1 July 2000 are also subject to goods and services tax.

\section{Supplementing the data}

An interesting research question - and one with practical consequences for book buyers - is whether auction houses systematically understate or overstate price estimates in pre-sale materials. Comparing auction prices with auctioneers' estimates is straightforward. These estimates are frequently published in auctioneers' catalogues, and they would be a valuable addition to the data in $A B A R$, so much so that we encourage the publishers to include estimates in future editions. $\underline{[5]}$

The $A B A R$ data could also be supplemented with information from other types of book sales. Many booksellers distribute printed catalogues in the post; it would be interesting to 
study how the asking prices in these catalogues differ from auction prices. Bookshops and bookfairs are other sources of asking prices, as are book catalogues published on the internet. The limitation of such data is that, unlike auction records, we cannot tell if the asking price has been accepted by a buyer.

Books are well-represented in on-line auctions, and these are another source of supplementary data. The advantage of on-line auctions for data collection is that every stage is widely broadcast and the sequence of bids is relatively easy to document. We say more about on-line auctions below.

Publications like Book Prices Current and Huxford's Old Book Value Guide attempt to provide schedules of benchmark prices of antiquarian books as an aid to book buyers (and booksellers), and these are another source of book 'price' data.

\section{Limitations of the $A B A R$ data}

When items are 'passed-in' (ie. they fail to reach their reserve price and are withdrawn from the sale), some auctioneers include the highest bid in their lists of prices realised. The publishers of $A B A R$ have attempted to purge the data-set of these rogue prices by excluding items known to have been passed-in, but they acknowledge that some phantom transactions may have crept in.

For a sale to be included in $A B A R$, a catalogue of lots must have been issued before the sale, and a price-list circulated afterward. Sales of books at auctions without these documents escape the data-set. $A B A R$ also does not document sales where several unrelated or loosely related books are sold as a single lot. Nor does it document sales of books that are not 'of Australasian interest'. Because these books and multi-book lots are excluded, and because some auctions are not represented in the data-set, we can infer that the total value of books sold by auction in Australia in 1999 was probably somewhat more than $\$ 840,000$. We can also conclude that the data are not very suitable for drawing conclusions about the level of activity in the book auction circuit.

We mentioned above that the data are useful as an indicator of the availability of different titles. However to the extent that the database is not comprehensive of all 'Australasian' books auctioned, it is that much less reliable as a guide to availability.

The compilers have taken pains to ensure that the $A B A R$ entries are bibliographically accurate. Yet the publishers acknowledge that some bibliographic gaps and shortcomings exist in the data-set. It would be useful if the publishers issued lists of errors that had been identified. These lists might be published as an appendix to later volumes, or in the form of a supplement to the series.

\section{Concluding comments}

Despite these limitations, Australian Book Auction Records is a useful resource for librarians and other people with a personal or professional interest in books. The data permit the analysis of auction results across time and space, across different types of auction events, across different firms of auctioneers, and across numerous other 
dimensions. They are an indispensable price guide for the acquisitions librarian, and reveal some interesting fashions in the tastes of buyers of Australiana. As the records are drawn from many different auctioneers and are organised bibliographically, $A B A R$ has obvious advantages over a large collection of auctioneers' catalogues.

To date, $A B A R$ has focused overwhelmingly on book auctions in Australia. Yet the market for Australasian books is not confined to one or two countries, or even to the Englishspeaking world, but transcends geographic, cultural and linguistic boundaries. This is particularly true in relation to books about Antarctica and the exploration of the Pacific. Many foreign auctions of Australiana, including important sales in Continental Europe and the United States, have evaded the $A B A R$ data-set. This is at odds with $A B A R$ 's intention to record sales of books 'of Australasian interest' rather than just Australian book auctions. In our view, the compilers of $A B A R$ should cast their net wider, especially outside Australia and Britain.

In the last few years, internet auctions have grown from a minuscule base to become an important part of the book auction circuit. Internet auctioneers like eBay (http://www.eBay.com), GavelNet (http://www.GavelNet.com), SOLD (http://www.SOLD.com.au), Auctions.com (http://www.auctions.com) and Amazon Auctions (http://www.amazon.com/auctions) have facilitated the sale of a large amount of rare and collectable material. Auctioneers of this kind will increasingly reduce the significance of where a particular auction is held. The location of an auction event matters less if there is no actual saleroom and anyone anywhere can join in on an equal footing.

In some ways, the profusion of on-line auctions will make the job of collecting book auction data easier. Information about items for sale and about when auctions will be held is available in real time twenty-four hours a day from the Web-auction sites. It is also possible to follow the sequence of highest bids electronically in real time. For these reasons, the publishers of $A B A R$ will face a growing case for including on-line auction results in future volumes of the series. The next $A B A R$ volume (2000-01) presents an opportunity for the compilers to include internet auction results. In our view, the compilers of $A B A R$ should seize this opportunity. If internet auctions don't go away (which is almost certain), and if they continue to grow (which is likely), $A B A R$ will be that much less representative of Australasian book auction results if internet auctions continue to be excluded. 


\section{References}

Dedman, Roger (1996) Australian Art Market Movements Handbook, Roger Dedman, Barker, Victoria.

Learmount, Brian (1985) A History of the Auction, Barnard \& Learmount, London.

[1] There are two other charity auctions in the records, one at Monash University, Victoria (1972) and one held by the MS Society in Camberwell, Victoria (1976). How prices differ between charity and non-charity auctions may shed light on the effect of bidder psychology on auction outcomes.

$[2]$ The figures were adjusted using the quarterly consumer price index figures in Australian Bureau of Statistics catalogue no. 6401.0.

[3] Roger Dedman has documented a similar phenomenon in Australian art auctions. Dedman's 'art market index' peaked almost a year after the sharemarket crash (Dedman, 1996). He also presents evidence that the art market crashed in Australia before it did in North America.

[4] The nominal value of 1997 sales was $\$ 1.82$ million.

[5] As is usually the case in auctions of paintings, book auction estimates are typically given as a price range. While the precise range is useful information, publishing the mid-point of the range would be an adequate second-best.

This document may be circulated freely

with the following statement included in its entirety:

Copyright 2000

This article was originally published in

LIBRES: Library and Information Science

Electronic Journal (ISSN 1058-6768) September 30, 2000

Volume 10 Issue 2.

For any commercial use, or publication

(including electronic journals), you must obtain

the permission of the authors.

\section{Fiona Kells}

School of Fine Arts, Classical Studies and Archaeology

University of Melbourne

and

\section{Stuart Kells}

Department of Economics 
University of Melbourne

quarle@,ozemail.com.au

To subscribe to LIBRES send e-mail message to

listproc@info.curtin.edu.au

with the text:

subscribe libres [your first name] [your last name]

Return to Libres 10n2 Contents

Return to Libres Home Page

CRICOS provider code: 00301J 